\title{
Pemanfaatan Limbah Cangkang Kerang Menjadi Cinderamata
}

\author{
Syahmidarni Al Islamiyah ${ }^{1 *}$, Rosdiani Azis ${ }^{1}$, Adnan Engelen ${ }^{1}$ \\ ${ }^{1}$ Prodi Teknologi Hasil Pertanian Politeknik Gorontalo \\ JL. Saptamarga Bone Bolango 96112 Gorontalo \\ "E-mail : islamiyah01@poligon.ac.id \\ DOI: https://doi.org/10.21107/pangabdhi.v7i1.9883 \\ Naskah diterima 9 Februari 2021, Revisi 28 Februari 2021, Terbit 29 April 2021
}

\begin{abstract}
One of the organic wastes that can be used for handicraft goods is Seashell. One of the artisanal items is a souvenir. The use of this waste is a type of community-owned skill. By using shell waste that has added value, this community service aims to make souvenirs. The methods in this activity include material presentation, discussion and training. The results obtained in this community service activity include 1) a lot of shell waste in Tanjung Kramat Village, Hulonthalangi District, Gorontalo District, Gorontalo Province, which can be made into souvenirs as souvenirs from the area;2) participants in community service have the skills and experience to make shell souvenirs. The conclusion of this activity is to learn information and skills to use shellfish waste as souvenirs for individuals who engage in this service. The proposal for this operation to be carried out on an ongoing basis is to pursue special government assistance to grow it into a community-based economic activity and to promote Tanjung Kramat tourism.
\end{abstract}

Keywords : seashell, waste, handicraft, tourism

\section{PENDAHULUAN}

Gorontalo merupakan provinsi yang memiliki sumber daya perairan yang melimpah. Salah satunya adalah Kelurahan Tanjung Kramat Kecamatan Hulontalanghi. Kelurahan ini terletak sekitar 20 menit dari Kota Gorontalo. Sebagian besar wilayahnya berupa pesisir pantai sehingga banyak sumber daya perairan yang sangat potensial dikembangkan. Potensi perairan yang banyak dan belum dimanfaatkan oleh masyarakat setempat adalah cangkang kerang. Bagian kerang yang diolah umumnya adalah dagingnya, sedangkan cangkangnya dibuang dan berakhir menjadi sampah. Cangkang kerang ini dapat diolah menjadi produk kerajinan yang bernilai tinggi seperti cinderamata. Cinderamata adalah tanda mata; pemberian; sebagai kenangkenangan. Menurut Agustini et.al (2011), bahwa memanfaatkan kulit kerang yang mengandung unsur mineral dan senyawa kimia alami untuk berbagai produk, sehingga dapat meningkatkan nilai tambah (added value).

Potensi cangkang kerang tersedia dimanamana dengan cangkang kerang yang memiliki bentuk dan keindahan. Bentuknya pipih dan ada pula yang menyerupai tanduk berduri, semuanya dapat digunakan untuk kerajinan tangan. Jenis cangkang kerang ada dua macam, yakni yang berpasangan dan ada yang tidak berpasangan (spiral). Bentuk berpasangan selalu memiliki alur garis permukaan yang mengarahkan dari engsel menuju ke tepian. Sedangkan motif cangkang tidak berpasangan pada permukaan luar melengkung mengarahkan ke bagian pusat, selain bagian atasnya tampak melebar. Beragam bentuk kerang laut ternyata bisa di buat menjadi aneka bentuk kerajinan tangan yang unik dan lucu serta bermanfaat.

Berdasarkan kondisi diatas maka potensi cangkang kerang ini dapat dimanfaatkan untuk berbagai macam jenis sovenir, atau cinderamata yang dapat bernilai ekonomis. Hal ini sesuai dengan pendapat Agustin et.al (2017) yang juga menyatakan bahwa selain sebagai souvenir dan pakan ternak limbah cangkang kerang dengan kandungan kalsium yang tinggi pada tulang ikan, sangat memungkinkan untuk dihasilkan produk dengan nilai tambah yang lebih tinggi. Pemanfaatan cangkang kerang telah banyak dilakukan seperti sebagai bahan campuran paving block (Kusuma, 2012), pembuatan pasta gigi (Budiarto dan Adiwarna, 2013) dan menjadi cinderamata untuk meningkatkan ekonomi rumah tangga (Supriadi, 2021).

Tanjung Kramat selain kaya akan sumber daya perairan juga terkenal dengan 
pemandangan alamnya yang indah berupa pantai yang panjang dengan jejeran bukit tinggi serta air laut biru yang jernih dengan kombinasi pasir dan kerikil di pesisir pantainya, sehingga menjadikan kelurahan ini sebagai salah satu objek wisata alam di Provinsi Gorontalo. Oleh karena itu, membuat berbagai cinderamata dari cangkang kerang sangat tepat sebagai oleh-oleh khas kelurahan ini.

Berdasarkan informasi di lapangan diperoleh bahwa di Kelurahan Tanjung Kramat terdapat kelompok dasawisma yang terdiri dari istri nelayan yang sebagian besar berprofesi sebagai ibu rumah tangga. Permasalahan yang dihadapi adalah mereka belum memiliki pengetahuan dan keterampilan membuat cinderamata dari cangkang kerang. Oleh karena itu, tim melaksanakan pengabdian ini untuk memberi pengetahuan dan keterampilan membuat berbagai cinderamata dari limbah cangkang kerang. Kegiatan ini sejalan dengan program Kementerian Kelautan dan Perikanan (KKP) yaitu membekali masyarakat di masa pandemi dengan keterampilan di baik pada subsektor budidaya, penangkapan, maupun pengolahan dan pemasaran hasil perikanan (Widjaja, 2020).

\section{METODE}

Kegiatan pengabdian ini dilaksanakan pada bulan Februari 2021 di Kantor Kelurahan Tanjung Kramat Kecamatan Hulonthalangi Kabupaten Gorontalo Provinsi Gorontalo. Metode pelaksanaan kegiatan pengabdian ini adalah pemaparan materi, diskusi dan pelatihan. Adapun tahap pelaksanaan kegiatan ini terdiri dari:

- Tahap pra-kegiatan yaitu tahap koordinasi dengan pihak pemerintah setempat dan persiapan kegiatan pengabdian.

- Tahap pelaksanaan kegiatan terdiri dari pemaparan materi dan diskusi dengan peserta pengabdian.

- Tahap pelatihan terdiri dari persiapan alat dan bahan serta praktek pembuatan cinderamata.

\section{HASIL DAN PEMBAHASAN \\ Pra Kegiatan}

Tahap pra kegiatan dilakukan dalam rangka berkoordinasi dengan pemerintah setempat mengenai potensi yang ada yang belum dimanfaatkan oleh masyarakat dan permasalahan yang dihadapi. Dari hasil koordinasi diperoleh informasi bahwa salah satu sumber daya perairan yang banyak tersedia di Kelurahan Tanjung Kramat dan belum dimanfaatkan oleh masyarakat adalah cangkang kerang. Dengan melihat bahwa Kelurahan Tanjung Kramat merupakan salah satu kunjungan wisata di Provinsi Gorontalo, maka tim berinisiatif untuk melakukan pengabdian tentang pembuatan cangkang kerang menjadi berbagai cinderamata sebagai oleh-oleh khas Tanjung Kramat dengan memberdayakan kelompok ibu Dasawisama yang telah ada. Adanya pemanfaatan limbah cangkang kerang yang semula tidak berguna menjadi produk yang memiliki nilai estetika dan nilai jual tinggi (Widyastuti, 2019). Kegiatan pemberdayaan ini menjadi media pendayaguaan modal penciptaan lapangan kerja bagi masyarakat (Erwin et al., 2013).

\section{Pelaksanaan Kegiatan}

Tahapan pelaksanaan kegiatan terdiri dari sesi presentasi yaitu pemaparan materi pengabdian dan diskusi. Materi pengabdian disusun dalam bentuk paparan power point dan video. Setelah peserta mengikuti pemaparan materi, ibu-ibu kelompok dasawisma telah mengetahui dan memiliki gambaran tentang cara membuat berbagai cinderamata dari cangkang kerang.
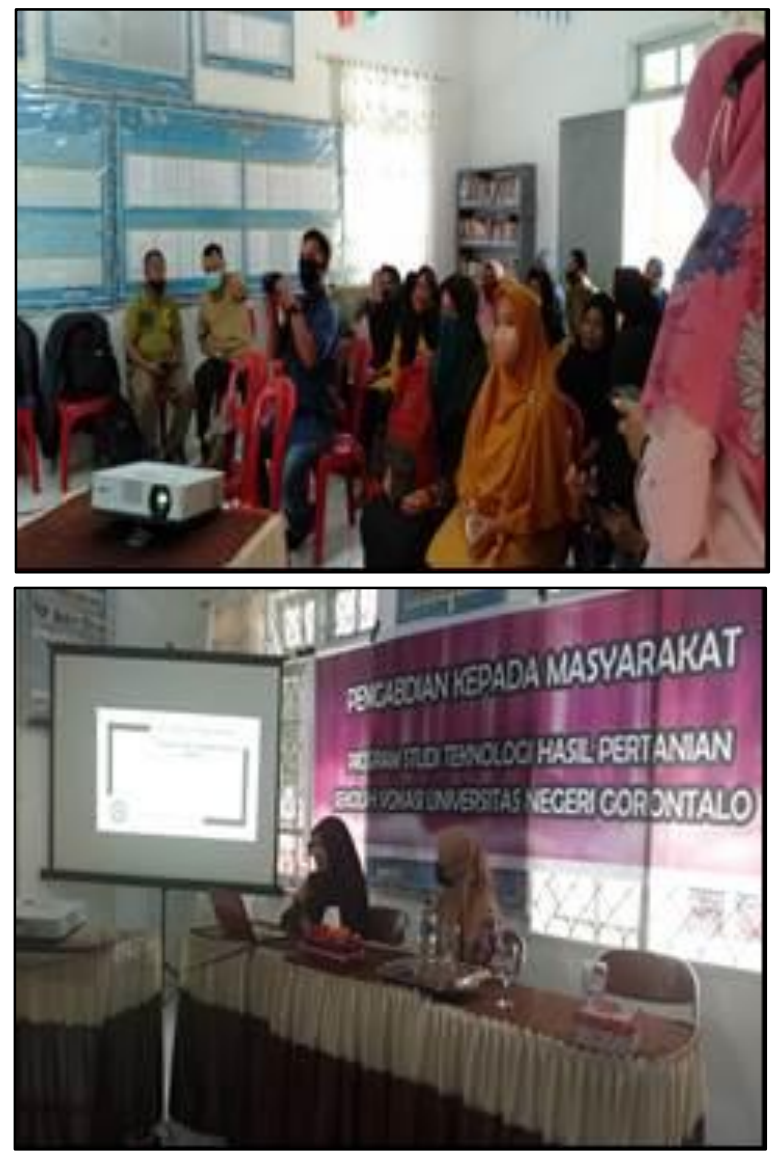

Gambar 1. Pemaparan Materi Pengabdian Masyarakat 


\section{Pelatihan Pembuatan Souvenir}

Setelah peserta memiliki pengetahuan pada tahap ini peserta dilatih cara membuat cinderamata dari cangkang kerang. Tim melatih peserta dengan tetap melibatkan peserta secara langsung. Pada tahap ini pelatih memperlihatkan bahan dan alat apa saja yang dibutuhkan dalam membuat cinderamata tersebut seperti cangkang kerang yang telah dibersihkan, pasir laut, alat tembak lem (glue gun), lem lilin, kuas kecil, lem fox, vas bunga, asbak, hiasan (manik-manik, gliter). Setelah mengikuti tahap pelatihan ini, peserta telah memiliki keterampilan membuat cinderamata dari cangkang kerang berupa vas bunga dan asbak seperti terlihat pada gambar di bawah ini.

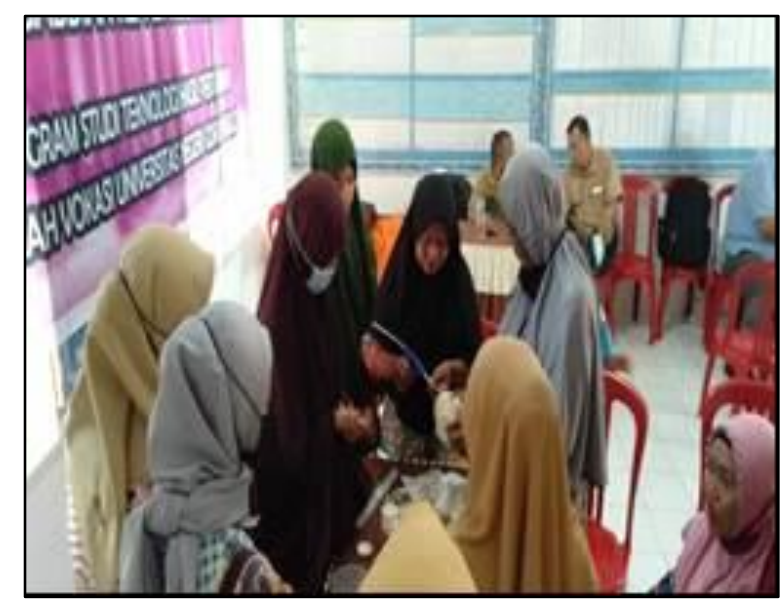

Gambar 2. Pelatihan Pembuatan Cinderamata

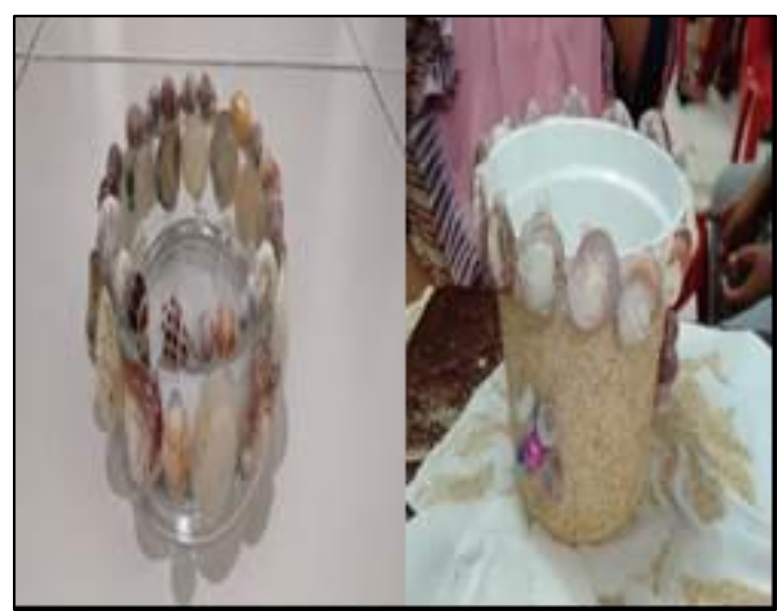

Gambar 3. Produk Cinderamata

\section{KESIMPULAN}

Berdasarkan hasil kegiatan pengabdian kepada masyarakat di Kelurahan Tanjung Kramat ini, kesimpulan yang dapat diperoleh adalah bahwa kelompok Dasawisma setelah mengikuti kegiatan telah memiliki pengetahuan dan keterampilan memanfaatkan limbah cangkang kerang menjadi cinderamata. Adapun saran untuk keberlajutan kegiatan ini yaitu adanya pendampingan khusus dari pihak pemerintah untuk dikembangkan menjadi kegiatan ekonomi masyarakat dan penunjang wisata Tanjung Kramat.

\section{DAFTAR PUSTAKA}

Agustini, W., Fahmi, T., Suhaedi, A., Widowati, I \& Sarwono, A. (2011). Pemanfaatan Limbah Cangkang Kerang Simping (Amusium pleuronectes) dalam Pembuatan Cookies Kaya Kalsium. Jurnal Pengolahan Hasil Perikanan Indonesia. Vol 14 (1). 8-13 pp.

Budiarto, H \& Adiwarna, A. (2013). Pengaruh Konsentrasi Gliserin Terhadap Viskositas Dari Pembuatan Pasta Gigi Cangkang Kerang Darah. Jurnal Konversi. Vol 2 (1).

Erwin, T. et al. (2013). Pengaruh modal sosial terhadap perilaku kewirausahaan; Suatu studi pada pelaku usaha mikro kecil menengah di Kecamatan Kabaruan Kabupaten Kepulauan Talaud. Jurnal Acta Diurna. Vol 2 (2). 1-10 pp.

Kusuma, E. W. (2012). Pemanfaatan Limbah Kulit Kerang Sebagai Bahan Campuran Pembuatan Paving Block. Skripsi. Universitas Pembangunan Nasional Veteran Jatim.

Supriadi, N. (2021). Pemberdayaan masyarakat melalui pelatihan desain kerajinan kulit kerang untuk meningkatkan perekonomian rumah tangga. Panrita Abdi : Jurnal Pengabdian pada Masyarakat. Vol 5 (1). 41-50 pp.

Widjaja, S. (2020). Tekuni kerajinan cangkang kerang, bidik peluang usaha dan lestarikan lingkungan. Akses : 4 Februari 2021, https://kkp.go.id/artikel/22039-tekunikerajinan-cangkang-kerang-bidik-peluangusaha-dan-lestarikan-lingkungan http. 